\title{
THE POWER AND DISCRIMINATION OF WOMEN AS SEEN IN JANE AUSTEN'S \\ PRIDE AND PREJUDICE
}

\author{
GESMALONI $^{1}$ \\ RAFLIS $^{2}$ \\ HELMITA $^{3}$
}

\author{
Volume 1 Nomor 1 \\ JILP \\ ISSN: 2581-0804 \\ E-ISSN: 2581-1819
}

\begin{abstract}
There is always discrimination against women in any field, as experienced by the main character Elizabeth Bennet in the novel Pride and Prejudice. Because women can not accept the inheritance from their fathers, therefore women are required to marry rich men to improve social class and economic life. Discrimination of women in the inheritance of wealth makes women have to struggle in finding rich men to marry. In the data analysis method the author performs a systematic procedure with a novel understanding, the main character of Elizabeth Bennet and also feminist theory, the technique

used in this research is a structural technique by analyzing novels based on the elements that make up.

The results of this study found that: 1) the discrimination of women in the inheritance of his father's estate, 2) the main character of Elizabeth Bennett describes the strength of women, because of his firm and wise in facing all problems in his life, 3) the women's struggle was carried out by Elizabeth Bennet in Find his true love and marry on the basis of love until it ends happily, but so many obstacles he faces both from the outside and from himself.
\end{abstract}

Keywords: feminist, power of women, discrimination and women struggle.

\section{ABSTRAK}

Selalu ada diskriminasi terhadap wanita dalam bidang apapun, seperti yang dialami tokoh utama Elizabeth Bennet dalam novel Pride and Prejudice. Karena wanita tidak bisa menerima harta warisan dari ayahnya, maka dari itu wanita diharuskan menikah dengan laki-laki kaya untuk meningkatkan kelas sosial dan kehidupan ekonomi. Diskriminasi wanita dalam pewarisan harta membuat wanita harus berjuang dalam menemukan laki-laki kaya untuk dinikahinya. Dalam metode analisis data penulis melakukan prosedur sistematis dengan pemahaman novel, tokoh utama Elizabeth Bennet dan juga teori feminist, teknik yang digunakan dalam penelitian ini adalah teknik struktural dengan cara menganalisis novel berdasarkan unsur-unsur yang membentuknya.

Hasil penelitian ini menyatakan bahwa: 1) adanya diskriminasi wanita dalam pewarisan harta dari ayahnya, 2) tokoh utama Elizabeth Bennet menggambarkan adanya kekuatan wanita, karena sifatnya yang tegas dan bijaksana dalam mengahadapi semua masalah dalam hidupnya, 3) perjuangan wanita dilakukan oleh Elizabeth 
Bennet dalam menemukan cinta sejatinya dan menikah atas dasar cinta hingga berakhir bahagia, namun begitu banyak kendala yang dihadapinya baik dari luar maupun dari dirinya sendiri.

Kata kunci: feminist, kekuatan wanita, diskriminasi dan perjuangan wanita.

\section{INTRODUCTION}

In Pride And Prejudice can be found discrimination of women that is the women can not get inheritance from her parents, beacuse the law of inheritance it is will be get by son in family. And in the Bennet's family have not son, so her nephew from her dad after he died will get all of they are inheritance and then the women must marry with rich man to increase social class and economic. The power of women in novel Pride And Prejudice as seen as main character that is Elizabeth Bennet is happy and not spoiled, for example when she walks away alone on the rain and past of forest to visit her sister Jane Bennet gets a sick in Mr.Bingley's home and when Lady Catherine de bourgh comes to Longbourn and insults her family however she always resists of words from the honor lady. Lady Catherine said "it is well. You refuse, then to oblige me. You refuse to obey the claims of duty, honour and gratitude.

The novel is about human critique of social life through a novel or novelist can use the literary works as media to send the idea or the

\section{REVIEW ON FEMINISM}

In general, feminism analysis talks about the equal right to differentiate gender that is between women and men. This point of view is to break the unbalance justice that creats a separation wall between those genders. According to Kennerman in Linda Nicholson (1990:205) who state that "feminism, the thought as action of people who want to make women's (legal,political,social,education,etc) rights equal to those of men". This quotation shows us how the society put some differences in some aspect such as education and jobs opportunity to women.

The feminism is begun by emancipating of women in release process from low social economic class and law treating which limits the possibly in developing in rising. Feminism raises based on the gender prejudices that tend to put women in number two because of the perception critique all of them are using language that call is literary works, can use separate between litarature and language. Such as Griffith (1982:1), "says Literature gives pleasure, it has a certain magic that transport us from the real world to seemingly more remote and enjoyable place". People who read literature will get enjoyment because it gives information, knowledge and experience about human daily life. literature is a context of ideology, when the author shows the idea through the characters and figure in the text in social reality in that decade. A novel express some aspect of human's love,existance and class society. Because novel talks about human activities and describes what happend in surounding, so it is written in long composition. "Novel is generally thought of as countaining about forty five thousand word or more" (Kennedy,1966:103). So novel is longer narrative than short story and novella. Novel as literary works has known since eighteen century in England.

of different between two genders. The limitation is not only on sexes differentiates bbut also in education, law, politic, social status and employee. The different treating based on the different of function physically. The different gender also creates the elimination for women to develop themselves. In addition the value of education not only become a measuring in judging the women, but their wealth also shape judgment toward them, to be valued higher or not in their society.

The phenomenon movement begun in some life aspect such as education, employment justice thet will become a way to break the rule. Those are some factors of women and also the power ponit of view in feminism into the movement it self. In supporting the tendency of feminism in struggling, the writer also present the function of women in their society and then 
perception to the world feminism it self. Feminism is concerned with the marginalization of all women that is, with their being relegated to a secondary position. It means that there is discrimination on women's life that should be showed and protested. Finally the writer concludes that feminism talk about the point of view, which change the relationship between women and men in the society. The relationship is also link all life structural such as education, cultural and as certain "who"what and for"who"the women will be.

The establishing of feminism is influenced by different treatment on women in politic, that can be seen in one statement of American Independent Declaration, that is "all men are created equal", without saying and talking about women. It's clear thhat women never been attention in politic and united. Beside that, for certain political purpose people consider that women relegated to a secondary position or lower class where women cannot be a leader for group of men. In economic aspect, women have no right to get a job like men. In this case women just can get job, such as baby-sitter, house maid, sewing, coking, taking care of children and all job have to do with home works or women duties in home, or eople always say that is women's duty. Even, women just can depend themselves on man by marrying man have a good financial. Therefore, most of women married with man without love.

Social aspect is also very influence on rising of feminism. As Encyclopedia Encarta say thta "the women's rights movement with new ideas about patriarchy. Feminism thinkers believed that patriarchy signified the cultural and social domination of women by men'. So, that patriarchy system is very unjust for women, where in society women have to follow their men's words eventhough it's not what they want. That's why women cannot develop themselves in any kind of life aspect. This system is also part social structure in society where this structure makes discrimination on women. Social structure that appears and develops in society makes differenced of gender to be injustice of gender.

As Mansour says in Analisis Gender and Transformasi Sosial, who state that

\footnotetext{
"Keyakinan yang menyatakan bahwa laki-laki adalah kuat, perempuan adalah lemah, adalah sama sekali bukan kodrat Tuhan atau takdir,
}

melainkan sebuah pembedaan yang di tetapkan oleh sebuah prose sejarah yang panjang".

The belief that men are strong, women are weak, is by no means the nature of God or destiny, but a distinction set by a long historical process (transleted by writer).

So, it's clear that injustice of gender is caused by social structure and it's not or created by God, because in reality there are so many strong women and in the meantime there are also many gentle men and emotional in society, and wether women or men, both of these genders are victims, but in this time women's position being in unlucky side.

\subsection{Demands of the Feminist}

Feminism movement is begun in Nineteenth Century in Englandin general when they have to face different treating, education and justice. The long periode of movement is influenced by education as an important basic in feminism. The limited perception in feminism in Romantic Era is caused by social condition at that time. The structure of society and the way of thinking create their own characteristic in understanding the feminism. In some structure of society level are to complete in raising their level. Some of society level deny the feminism because of less education that they had.

Education is important thing in measuring the class of society. In Nineteenth Century, men got more education-compared women. So, many schools are just for them but less for women. Long time ago school is built for women just in order to learn how to cook, how to sew and manage their house without any opportunities to learn other knowledge in politic, science and etc. As result in early Nineteenth Century women break the old rule about the feminism and change the world point of view in feminism and demand education as first atep to their gender.

The education demanding is creates other demanding in law, economic and social. In the first time feminism stands on economic demanding based on their opinion that wealth is an important thing in struggling their gender. In society education is not only in the form of writing, reading without opportunity to continue the highest level. At the time they only have education to support their function as a mother 
not a player in their own society in general. In some sources the writer takes some portraits of education perception that also able to actually is education the vision about the feminism it self.

The writer finds the limitation of opportunity for the women to get the highest education and their function to develop the education it self. In other side, it can be stated that the education is the main way for the women to get their own function to change their status not only as a mother a housewife but maybe can be a president in a country. If the women still not considered about the important function of educations it self they will not be success to change their gender function. The modern feminism considered that education as a road get the women developing in their function.

It is clear that education has taken part in the feminism to make the equal position between women and men. The relevancy on this case is that women have to get the education. The education it self in sexual stereotype will not give a certain benefit to women in a specific right in feminism. Some people give their opinion thaht education structure, which connect the unbalance gender position in opportunity to get the education.

Beside the education aspect that has become the women demanding. In this chapter the writer tries to analyze the feminism in the employment perception. In economical aspects, the raise of economic tends to challenge the men in fulfilling the family's need compare with women. The raise of price and also the daily need, force women to take a part in labor automatically will change the function of women in their social life. In fact the husbands get jobs it is considered as the main duty as a father to become a breadwinner in his family, but not in women position as labor in fulfilling their need, the society considers their salaries as the additional benefit in family. The women's tedency in structural changing is never get public attention in their effort to support their family in. Marxis feminism the women's labor put as the additional labours, which not become the main labour with all intimidation. The diving of labour in sexual differences become the other agenda in it self.

In other side women stand is poverty that demand them have to find the additional money to fulfill their family's need. The borjouis women who independent in wealth against the women labour as their community. This condition creates the certain society lass in women it self. The women also get the impact of changing in labour side that make women's have their duties in house as wishes. Under this circumstances women the women situated under pressure of her condition.

The economic pressure has forced the women to do something beyond their ability. To become labour is out of the women's abilities it is compared with men physically. Even it is very important in feminism in depending themselves economically in the same tretment also the discrimination in their society and women's struggle in employment aspect is one of women's struggle in feminism.

\subsection{Theoretical Framework}

To support the analysis of the study, the writer employs only one approach and some relevant theories. Application $f$ these approach and theories is expected to sharpen the result of the analysis and preventing the deviation of the analysis.

In doing this analysis, the writer take some theories and one approach. Femiinist approach is taken by the writer in this writing, which talks about the problems and experience of woman because the work that is used talks about a discrimination of knowledge for a woman where the situation sacrifice woman. They did not have any oppportunities to continue their study likemen did, and only was responsibility at home. In other word, women were prepared for being married not to be active out of house as a labor woman.

Based on the idea, we know that feminism approach is rooted from fundamental intuition that woman are seated of consciousness. Women are written in literature for the most part as object to show the important side of them. The novel that the writer analysis is focused in gender studies beacuse there is a attempt of woman to have an equally as a man can do. As Soenarjati Djajanegara (2000:19) says,

Kritik sastra feminis membeberkan perempuan menurut stereotype seksual, baik dalam kesustraan maupun dalam kritik sastra, dan juga menunjukan bahwa aliran-aliran serta cara-cara yang tidak memadai telah (digunakan untuk) mengkaji tulisan perempuan secara tidak adil, tidak peka

Feminist literary criticism exposes women according to sexual 
stereotypes, both in literature and in literary criticism, and also shows that inadequate streams and methods have been used to study women's writings unjustly (translete by writer)

Then, this approach is concerned with the impact of gender on writing and reading. Clearly, it can be assumed that female character within Pride and Prejudice lacks authenticity if they are not portrayed as the complex and unique individuals. Generally, women are represented as a subordinate class. Too often women are merely streotypes that allow the male protagonist to dfine his own role and fulfill his own selfhood. In response to this misrepresentation of women in literature, feminist criticism has necessarily often become a negative one, resisting streotyped images of women. The feminist response to culture that has united in the las half of the twentieth century recognizes a deeply ingarained prejudice against women.

Furthermore, the writer applies the theory of liberal feminism to the power of women in pride and prejudice, liberal feminism believe in individualism and stress the importance of personal identity over gender identity. The main thing that makes it different with other feminist theories is that liberal feminist maintains the primary cause of women's subordination to men is a set of social norms and formal was that make it hard for women to succed in the public world. Unless women have the same opportunities the men have, women will not be able to achieve their full potential in the academy, forum, market place, operating room and so forth.

Then, the writer uses the theory First Wave Feminism to discrimination of women in pride and prejudice, this term refers to the first concerted movement working for the reform of women's social and legal inequalities in the nineteenth century. Although individual feminist such as Mary Wollstonecraft had already argued against the injustices suffered by women, it was not untill the 1850's that something like an organized feminist movement evolved in Britain. The key concerns of First Wave feminist were education,employment,the marriage laws and the plight of intelligent middle-class single women. They were not primarily concerned with the problems of working -class women, nor did they necessarily see themselves as feminist in the modern sense. First wave feminist largerly responded to spesific injustices they had themselves experienced.

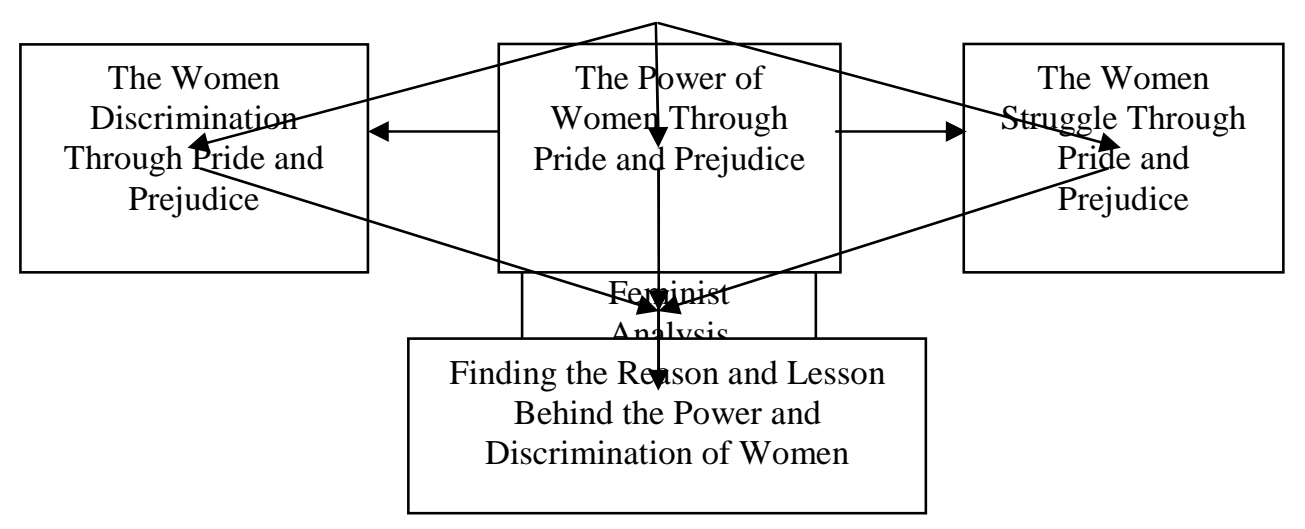

\section{METHOD OF THE RESEARCH}

This research is oriented in the library in order to find the related data, however it is not restricted in finding other written material from internet or even from the motion picture. According to Pradopo in Metodologi Penelitian Sastra (2001:153) states:

Penelitian pustaka adalah observasi yang dilakukan dalam pustaka, dimana penulis mendapatkan data dan informasi tentang objek penelitian melalui buku dan media audiovisual yang berhubungan dengan topic.

The library research is the 
observation that is executed in the library, which the writer gains the data and information about his object trought the books and other audiovisual equipment that related and relavant to the topic (translated by writer).

In order to gain more information, the writer also executes the internet research as to support the data from library research, the data was files form. Structural Dynamics is a type of structural analysis which covers the behavior of structures subjected to dynamic (actions having high acceleration) loading. Dynamic analysis can be used to find dynamic displacements, time history, and modal analysis. A dynamic analysis is also related to the inertia forces developed by a structure when it is excited by means of dynamic loads applied suddenly (e.g., wind blasts, explosion, earthquake).

Technique also means that is a way of work in understanding the object and the objective of the sceince involved with of contemporary English Technique is way of doing something ( Quirk,1987;681). The qualitative technique has four characteristics, namely : (1) Natural setting is data resources and researcher of a key instrument (2) The qualitative technique descriptively ,means that the data is explained in it (3) The form of word or picture is not statistic (4) The qualitative is considered as more important to process that result. The technique of analyzing the data read of the novel to find a some quotation to object of the study the power, discrimination and struggle of women, then the writer tries to interpret and explain it. At last the writer put it in the research as the result of the research.Then, the data is presented in a descriptive method that is by describing the fact about the novel focusing on those questioned the discrimination and the power of women.

\section{RESULTS OF RESEARCH AND DISCUSSION}

In the analysis of the power and discrimination of women, main character Elizabeth Bennet which is brave, firm, cheerful and feminis can proving not all of women will get married with the rich man without based on love. The writer uses the feminist theory to describe of the discrimination, the power and the struggle of women. The detailed of description can be seen in the following sub-chapters :
5.1. The Women Discrimination in Middle Era through Pride and Prejudice

Discrimination refers to unfair service to a particular individual, where the service is based on the characteristics represented by the individual. Various forms of discrimination that occur in life include: discrimination age, gender, health. Race, religion and people. One example of discrimination, that is : Some people who place men higher than women. And there is a gulf between the rich and the poor. In this research the writer uses the theory First Wave Feminism, this term refers to the first concerted movement working for the reform of women's social and legal inequalities in the nineteenth century. Although individual feminist such as Mary Wollstonecraft had already argued against the injustices suffered by women, it was not untill the 1850's that something like an organized feminist movement evolved in Britain.

The key concerns of First Wave feminist were education,employment,the marriage laws and the plight of intelligent middle-class single women. They were not primarily concerned with the problems of working-class women, nor did they necessarily see themselves as feminist in the modern sense. First wave feminist largerly responded to spesific injustices they had themselves experienced. Austen is certainly critical of the gender injustices present in 19th century English society, particularly as perpetrated by the institution of marriage. In Pride and Prejudice, many women (such as Charlotte) must marry solely for the sake of financial security. However, in her portrayal of Elizabeth, Austen shows that women are just as intelligent and capable as their male counterparts. Jane Austen herself went against convention by remaining single and earning a living through her novels. In her personal letters, Austen advised friends only to marry for love. In the novel, Elizabeth's happy ending reveals Austen's beliefs that woman has the right to remain independent until she meets the right man (if she meets him).

On the other hand, most contemporary readers will find the Longbourn entailment to be unjust. And yet the heroines - Jane and Elizabeth - refrain from speaking out against it. Instead, the only two characters who openly criticize the entailment - Mrs. Bennet and Lady Catherine are ridiculous caricatures. Furthermore, the fact that Elizabeth seems to share her father's distrust frivolous women suggests Austen's uneasy relationship with her own gender. 
Austen is certainly critical of the gender injustices present in 19th century English society, particularly as perpetrated by the institution of marriage. In Pride and Prejudice, many women (such as Charlotte) must marry solely for the sake of financial security. However, in her portrayal of Elizabeth, Austen shows that women are just as intelligent and capable as their male counterparts. Jane Austen herself went against convention by remaining single and earning a living through her novels. In her personal letters, Austen advised friends only to marry for love. In the novel, Elizabeth's happy ending reveals Austen's beliefs that woman has the right to remain independent until she meets the right man (if she meets him).

Money plays a central role to the plot of Pride and Prejudice. Because of the entail, the Bennet women will have a bleak financial future after Mr. Bennet dies. When readers recognize this, Mrs. Bennet's pursuit of husbands for her daughters takes on a sense of urgency that supersedes her foolish behavior. Translating the monetary realities that the characters of Pride and Prejudice face into modern equivalents helps readers to better understand the characters' motivations and the significance of their actions.

In the Austria (1811): married women were granted separate economy and the right to choose their professions. This is talks about the problems and experience of woman because the work that is used talks about a discrimination of knowledge for a woman where the situation sacrifice woman. They did not have any opportunities to continue their study like men did and only was responsibility at home. In other word, women were prepared for being married not to be active out of house as a labor woman.

[Colonel Fitzwilliam:] "But in matters of greater weight, I may suffer from want of money. Younger sons cannot marry where they like."

[Elizabeth:] "Unless where they like women of fortune, which I think they very often do."

"Our habits of expense make us too dependent, and there are not many in my rank of life who can afford to marry without some attention to money."

"Is this," thought Elizabeth, "meant for me?" and she coloured at the idea; but, recovering herself, said in a lively tone, "And pray, what is the usual price of an earl's younger son? Unless the elder brother is very sickly, I suppose you would not ask above fifty thousand pounds"

Here, Colonel Fitzwilliam slips Lizzy a little hint that, while he thinks she's cute and all, he's not about to marry her. He may be the son of an earl, but he's the younger son, which means he's not going to inherit the estate, unless his older brother dies. Lizzy recovers by making a joke about how much it costs to marry an earl's younger son (i.e., how much money does the girl have to bring to the marriage?) but Fitzwilliam is serious: he has to marry a rich woman to support him in the manner to which he's become accustomed, his "habits of expense." He's our clue that, while this system of marriage isn't great for women, it's not great for men, either.

In this discussion the writer focuses on the gender discrimination contained in the novel pride and prejudice by Jane Austen, that is the discrimination of women for injustice in receiving the inheritance owned by their own fathers. As the Bennet's family described it, because Mr.Bennet only has five daughters and no son, so after he died all the land and his estate property will fall down to his nephew Mr.collins. As Mr.Bennet said;

"After amusing himself some time with their curiosity he thus explained: "about a mounth agoi answer it ; for $i$ thought it a case of some delicacy and requiring early attention. it is from my cousin, Mr.Collins, who when i am dead my turn alll out of this house as soon as he pleases" (53)

But Mrs.Bennet did not understand the laws of the English inheritance at the time, like she said;

"I do think it is the hardest thing in the world, that your estate should be entailed away from your own children.and $i$ am sure, if $i$ had been you, i should have tried long ago to do something" (53)

The injustice made Mr.Bennet think to force her daughters to marry with a rich man, to 
raise the social class and preserve her daughter's economic life later. However, social class differences also constitute discrimination for Bennet girls from lower social classes and it is difficult for them to find a wealthy man from a social class. As Mr.Darcy said " but it must very materially lessen their chance of marrying men of any consideration in the world". (31)

From the above quote can be seen that social position is also an important thing for a marriage, for Bennet's girls who come from lower social class will find it difficult to marry men from the upper social class. Because, most of them just hang out from among them alone. In addition, women in the early nineteenth-century are not allowed in higher education, so private teachers and private schools have a structured education level open to them, so that women in lower social classes have only moderate skills and abilities.

5.2. The Power of Women in Middle Era through Pride and Prejudice

The main character in this novel Elizabeth Bennet reflects the power of women who oppose a culture of marriage that depends on wealth. As Elizabeth's main character faced many problems in her life, with all her abilities she could overcome and get her happiness. Elizabeth reflects Marxist feminism which shows women's problems within the framework of capitalism. He dared to change the image of society for the role of women in the family and he could change the look of marriage under capitalism in pride and prejudice.

Besides Elizabeth's character in this novel is also a girl who is cheerful, courageous, strong, joking and likes to laugh at things that are ridiculous. As he told his family, when he was worried and concerned about Jane's illness and wanted to visit him in the Netherfield.

"No need. I do not wish to avoid the walk, the distance is nothing when one has a motive; only three miles. I shall back by dinner. In Meryton they parted: the two youngest repaired to the lodgings of one of the officers wives' and Elizabeth continued her walk alone, crossing field after field at aquick pace , jumping over stiles and springing over puddles with impatient activity and finding. Herself at last within view of the house, with weary ankles, dirty stockings and a face

\section{glowing with the warmth of \\ exercise" (27)}

From the above quote, Elizabeth proves that she is not a spoiled girl, she has the courage and strength to find what she wants. In this story, he continues his own journey, crossing fields after field with swift steps, jumping over fences and puddles with agility, until finally he reaches his destination to find his sister. Elizabeth describes the character of a woman who has the power and can do the same with men, the power of Elizabeth taught that women can also do everything and not easily give up for something he wants to get with a strong stick.

"Despite how frequently literature and society have fictionalized and stereotyped females as angels, bar maids, bitches whores, brainless housewives, or old maids, women must define themselves and articulate their roles, values, aspirations, and place in society. To do so, say feminist critics, women must...marshal a variety of resources to assert, clarify, and finally implement their beliefs and values" (182)

In regard to this quote, Elizabeth Bennet indeed clarifies and implements her own beliefs and values. The protagonist, in a final spat with Lady Catherine de Bourgh, asserts her position on marrying Mr. Darcy, free from societal restrictions: "I am only resolved to act in that manner, which will, in my own opinion, constitute my happiness, without reference to you, or to any person so wholly unconnected to me" (260). As such, Miss Bennet articulates her own role and place in society, although still only as a housewife, but a housewife that marries for love and her own values as opposed to the societally dictated "values" of wealth and a vast fortune.

"As one of the most significant developments in literary studies in the second half of the twentieth century, feminist literary criticism advocates equal rights for all women (indeed, all peoples) in all areas of life: socially,politically,professionally,pe 
rsonally,economically,esthetically, and psychologically"(167).

Feminist literary criticism champions equal rights for women, so it would be apt to pay attention to an occasion in which Elizabeth Bennet claims equality with another upper-class man, Mr. Darcy. Again, in the same quarrel with Lady Catherine de Bourgh, Miss Bennet claims,

"In marrying your nephew, I should not consider myself as quitting that sphere [in which I have been brought up]. He is a gentleman; I am a gentleman's daughter; so far we are equal" (316).

In this instance, Miss Bennet claims equality with Mr. Darcy as she opposes Darcy's controlling aunt. To be equal to and have equal opportunity and rights with a man of such social ranking as Mr. Darcy is to epitomize the very cause of feminist literary criticism - to chiefly advocate for the rights and equality of women. The importance of marriage in the lives of Elizabeth Bennet and her sisters may be difficult for modern readers to understand. Young women today have a variety of options open to them regarding their future - they can marry, of course, but they can also go to college, follow any career path that may interest them, and live on their own, independent of relatives or chaperones. Young women of Austen's day did not have these advantages. Although the daughters of the middle and upper class could be sent to school, their education there consisted more of becoming "accomplished" than it did of expanding their academic knowledge.

Additionally, women in early nineteenthcentury Britain were not allowed in higher education, so private tutors, governesses, and private schools were the extent of structured education open to them. Naturally, a young woman like Elizabeth Bennet with a lively, inquisitive mind would have been able to further her education independently through reading. Elizabeth indicates as much to Lady Catherine, describing education for her and her sisters as being unstructured but accessible: "such of us as wished to learn, never wanted the means. We were always encouraged to read, and had all the masters that were necessary. Those who chose to be idle certainly might." In discussing a woman's accomplishments, Darcy also comments that a really commendable woman will improve "her mind by extensive reading."

A woman's formal education was limited because her job opportunities were limited- and vice versa. Society could not conceive of a woman entering a profession such as medicine or the law and therefore did not offer her the chance to do so. In fact, middle- and upper-class women had few avenues open to them for a secure future. If unmarried, they would remain dependent upon their relatives, living with or receiving a small income from their fathers, brothers, or other relations who could afford to support them.

In Elizabeth's case, she is dependent upon her father while he is living and she is unmarried, but because of the entail and the fact that she has no brothers, her situation could become quite desperate when he dies. She and her mother and sisters would be forced to rely upon the charity of their relatives, such as Mr. and Mrs. Phillips, Mr. and Mrs. Gardiner, and even Mr. Collins. Such a position would be extremely distasteful and humiliating.

Other options available to a gently bred young woman who needs to support herself would be to take a position as a governess or a lady's companion. Both jobs allowed a woman to earn a living without sacrificing her social position. However, the working conditions of these jobs were often unpleasant and degrading. Governesses might be preyed upon by the men in the family for which they worked, while lady's companions, such as Miss De Bourgh's companion, Mrs. Jenkinson, might be treated poorly by their employers and given menial tasks to attend to. Any other form of employment a woman could take was considered unacceptable and would most likely irrevocably harm her social standing.

An unmarried woman's social standing would also be harmed by her living alone, outside of the sphere of her family's influence. If a single woman who had never been married was not living with her family, she should at least be living with a suitable chaperone. Therefore, when the Bennet daughters travel in Pride and Prejudice, they always stay in the company of a relative or a respectable married woman. Jane visits the Gardiners, Elizabeth stays with the now-married Charlotte, Elizabeth later travels with the Gardiners, and Lydia goes to Brighton as the guest of Mrs. Forster. When Lydia runs away with Wickham, however, her reputation and social standing are ruined by the fact that she lived with him alone and unwed for two weeks. 
Only marriage can save her from being rejected by her social sphere, and only marriage can save her family's reputation as well, unless they disowned her. Consequently, Darcy's efforts to find Wickham and Lydia and to buy Wickham's marriage to Lydia quite literally saves not only Lydia's reputation, but the whole Bennet family as well.

5.3. The Women Struggle in Middle Era through Pride and Prejudice

Money makes the world go round, especially if you're a young woman trying to get married in Regency England. The five Bennet daughters have almost no money, which means no way to entice men to marry them and no way to support themselves after their father dies and their house in handed over to Mr. Collins. For men, there were very few paths to financial independence without either inheriting or marrying money. Some got rich in the army or through business, but that was super rare. For women, the options were even more limited: inherit or marry. In Pride and Prejudice, the Bennet girls aren't trying to marry for money because they want to buy a Lexus and vacation in St. Barts; they're trying to marry for money because they don't want to live on the early nineteenth-century equivalent of the streets.

Pride and Prejudice depicts a society in which a woman's reputation is of the utmost importance. A woman is expected to behave in certain ways. Stepping outside the social norms makes her vulnerable to ostracism. This theme appears in the novel, when Elizabeth walks to Netherfield and arrives with muddy skirts, to the shock of the reputation-conscious Miss Bingley and her friends. At other points, the ill-mannered, ridiculous behavior of Mrs. Bennet gives her a bad reputation with the more refined (and snobbish) Darcys and Bingleys. Austen pokes gentle fun at the snobs in these examples, but later in the novel, when Lydia elopes with Wickham and lives with him out of wedlock, the author treats reputation as a very serious matter. By becoming Wickham's lover without benefit of marriage, Lydia clearly places herself outside the social pale, and her disgrace threatens the entire Bennet family.

The fact that Lydia's judgment, however terrible, would likely have condemned the other Bennet sisters to marriageless lives seems grossly unfair. Why should Elizabeth's reputation suffer along with Lydia's? Darcy's intervention on the Bennets' behalf thus becomes all the more generous, but some readers might resent that such an intervention was necessary at all. If Darcy's money had failed to convince Wickham to marry Lydia, would Darcy have still married Elizabeth? Does his transcendence of prejudice extend that far? The happy ending of Pride and Prejudice is certainly emotionally satisfying, but in many ways it leaves the theme of reputation, and the importance placed on reputation, unexplored. One can ask of Pride and Prejudice, to what extent does it critique social structures, and to what extent does it simply accept their inevitability? This novel opens with the phrase,

"It is a truth universally acknowledged that a single man in possession of a good fortune must be in want of a wife...

"what is his name?"

"bingley".

"oh! Single, my dear, to be sure! a single man of large fortune ; four or five thousand a year. What a fine thing for our girls".(1-2)

The phrase shows marriage motif in this novel, if a man wants a wife, then a woman also wants a husband who has treasure. Charlote Lucas, Lydia Bennet, Jane Bennet and Elizabeth Bennett marry men who can provide for their needs. Marriage is economic rather than social. In this case Charlote, she married on the basis of economic comfort in marriage. Mr. and Mrs.Bennett's marriage is an example of marriage should not be like that. Elizabeth and Darcy were married because they loved each other after breaking the "pride" and "prejudice" between them and Austen left the impression that their marriage would be happier. But before getting happiness for her marriage to Mr.Darcy Elizabeth had to struggle to find her true love, because between her and Mr.Darcy did not have much in common.

Their interactions and criticisms of one another have made them realize that they have made mistakes and tried to fix them. Elizabeth is not a woman who just wants to marry a man for wealth, but she wants to be based on love, in search of a man who loves and loves her struggling to overcome obstacles from herself and others. Elizabeth also struggled for the distinction of social class position between her and Mr.Darcy, the problem was illustrated when Lady Catherine visited the Longbourn Bennet family's residence to meet Elizabeth, who was 
opposed to the issues she had heard about Elizabeth's marriage and her nephew Mr.Darcy Which he himself had long regarded as a fiancee of his own daughter Miss De Bourgh since they were from the upper social class of the equivalent and the wealthiest and wealthiest family in the UK. As for Elizabeth, he always looked down on his social class, but Elizabeth tried to fight for the difference in his position with Mr.Darcy to sound the equivalent of what he said,

"in marrying your nephew, I should not consider myself as quitting that sphere. $\mathrm{He}$ is a gentleman, I am a gentleman's daughter; so far we are equal.

"i have said no such thing. I am only resolved to act in that manner wich will, in my own opinions,

\section{CONCLUSIONS AND SUGGESTIONS}

Pride and Prejudice reflect the power and discrimination in the social life, critiques and comment upon the British landed gentry at the end of the 18th century. Austen's novel often explore the dependence of women on marriage in the pursuit of favourable social standing and economic security. The writer then provided the findings from this analysis:

1. The women discrimination in middle era through pride and prejudice, the women cannot get inheritance from her parents, beacuse the law of inheritance it will be get by son in family. And in the Bennet's family have not son, so her nephew from her dad after he died will get all of they are inheritance and then the women must marry with rich man to increase social class and economic.

2. The power of women in middle era through pride and prejudice. The main character in this novel Elizabeth Bennet reflects the power of women who oppose a culture of marriage that depends on wealth. As Elizabeth's main character constitute my happiness, without

referance to you, or to any person so

wholly unconnected with me" (316)

Elizabeth had the power for wage a struggle of the position his family social class and her pure love for the man she was going to marry, though a rich, respectable lady like Lady Catherine was oppose about the issue of Elizabet's married with her nephew.

So many problems faced by Elizabeth in discovering the happiness of her marriage and she continues to fight against anything that prevents her from discovering her true love, whether it comes from within her for being too prejudiced or from others who oppose her. Until finally she married a man who loved and loved him, so married on the bassis of love in the struggle to find happiness forever.

faced many problems in her life, with all her abilities she could overcome and get her happiness.

3. The women struggle in middle era through pride and prejudice. There is marriage motif in this novel, if a man wants a wife, then a woman also wants a husband who has treasure. Marriage is economic rather than social.

\section{A. Suggestions}

'For the writer, this research had been an effort to prove his study and at the same time to deepen his skill about literary work through writing. However, this analysis might not be perfect, so the writer wants certain inputs and critics from the readers in perfection of this writing. The writer hopes this analysis could add a new expression in literature world, especially English Department, Faculty of Letters, Ekasakti University. For the reader, the writer also hopes that this writing will give the contribution to the English Department students and whoever may be interested in the subject being discussed. 


\section{Bibliography}

Austen, Jane.1989. Pride and Prejudice. Leicestershire: F.A. Thorpe Ltd

Djajanegara, Soenarjati. 2000. Kritik Sastra Feminis. Jakarta: PT. Gramedia Pustaka Utama

Fakih, Mansour. 1996. Analisis Gender dan Transformasi Sosial. Jakarta: Pustaka

Pelajar

Griffith,J.K.1982.Writing Essay About Literature.United States of America:

Harcout Brace Jovanovich,Incs

Hawkesworth, Mary E. 2006. History and Theory of Feminism.Retrieved from the

website: https://www.gender.cawater_infonet/kn owledge baserubricator/feminisme.htm on November $6^{\text {th }}, 2016$ at 11:05 AM

Kennedy,William.1966.How To Analyze Fiction.New York: Monarch Press

Linda,C.Stanley.1985.Ways to

Writing.Cambridge: University Press

Pradopo, Rachmat Djoko, et.al. 2001. Metodologi Penelitian Sastra. Yogyakarta:

PT. Hanindita Graha Widia

Quirk,R.1987.Longman Dictionary of Contemporary English.London:

Longman 